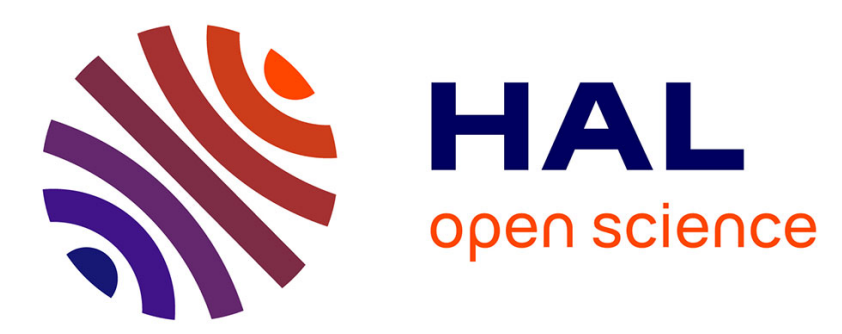

\title{
Investigations on glasses in the Sb2S3-Agl system
}

Sun Hong Wei, Bernard Tanguy, Jean-Maurice Réau, Jean-Jacques Videau, Josik Portier

\section{To cite this version:}

Sun Hong Wei, Bernard Tanguy, Jean-Maurice Réau, Jean-Jacques Videau, Josik Portier. Investigations on glasses in the Sb2S3-Agl system. Journal of Non-Crystalline Solids, 1988, 99 (2-3), pp.222-232. 10.1016/0022-3093(88)90432-2 . hal-00260939

\section{HAL Id: hal-00260939 \\ https://hal.science/hal-00260939}

Submitted on 9 Mar 2021

HAL is a multi-disciplinary open access archive for the deposit and dissemination of scientific research documents, whether they are published or not. The documents may come from teaching and research institutions in France or abroad, or from public or private research centers.
L'archive ouverte pluridisciplinaire $\mathbf{H A L}$, est destinée au dépôt et à la diffusion de documents scientifiques de niveau recherche, publiés ou non, émanant des établissements d'enseignement et de recherche français ou étrangers, des laboratoires publics ou privés. 


\title{
INVESTIGATIONS ON GLASSES IN THE $\mathrm{Sb}_{2} \mathrm{~S}_{3}-\mathrm{AgI}$ SYSTEM
}

\author{
Hong Wei SUN ${ }^{1}$, Bernard TANGUY, Jean-Maurice REAU, \\ Jean Jacques VIDEAU and Josik PORTIER
}

Laboratoire de Chimie du Solide du CNRS, Université de Bordeaux I, 351, cours de la Libération, 33405 Talence Cedex, France

New glasses have been prepared in the $\mathrm{Sb}_{2} \mathrm{~S}_{3}-\mathrm{AgI}$ system. A glass domain is observed from $0.90 \mathrm{Sb}_{2} \mathrm{~S}_{3}-0.10 \mathrm{AgI}$ to $0.33 \mathrm{Sb}_{2} \mathrm{~S}_{3}-0.67 \mathrm{AgI}$.

A structural approach is proposed on the basis of infrared spectroscopy studies. It shows the presence of $\mathrm{Sb}_{2} \mathrm{~S}_{2} \mathrm{I}_{4}$ groups such as those observed in $\mathrm{SbSI}$ and $\mathrm{SbS}_{3}$ pyramids like in $\mathrm{Sb}_{2} \mathrm{~S}_{3}$.

Thermal and chemical properties have been studied. Ionic conductivity has been determined. An Arrhénius behavior is verified between $25^{\circ} \mathrm{C}$ and $T_{\mathrm{g}}$ over the whole glass domain. A comparative study with glasses belonging to the $\mathrm{Sb}_{2} \mathrm{~S}_{2}-\mathrm{Ag}_{2} \mathrm{~S}$ system has been undertaken.

\section{Introduction}

In a previous study [1], we described the properties of glasses obtained by hyperquenching in the $\mathrm{Sb}_{2} \mathrm{~S}_{3}-\mathrm{Ag}_{2} \mathrm{~S}$ system. The ionic conductivity of these materials is relatively high $\sigma_{25^{\circ} \mathrm{C}}=5.6 \times 10^{-3} \Omega^{-1} \mathrm{~cm}^{-1}$ for the composition $0.10 \mathrm{Sb}_{2} \mathrm{~S}_{3}-0.90 \mathrm{Ag}_{2} \mathrm{~S}$ due to a glass structure analogous to that of silver sulfide). Taking into account the very similar structure of both silver sulfide and iodide, it was tempting to extend the previous work to the $\mathrm{Sb}_{2} \mathrm{~S}_{3}-\mathrm{AgI}$ system.

This system has already been investigated by Mentus et al. [2], and they found a glass for only one composition $\left(0.40 \mathrm{Sb}_{2} \mathrm{~S}_{3}-0.60 \mathrm{AgI}\right)$.

\section{Experimental}

\subsection{Glass preparation}

The starting materials are silver iodide (purity 99\%; Aldrich $\mathrm{Co}$.) and $\mathrm{Sb}_{2} \mathrm{~S}_{3}$ (purity 99\%, Ventron Co.).

${ }^{1}$ Permanent address: Shanghai Institute of Optics and Fine Mechanics of the Chinese Academy of Science, Shanghai, PRC. 
Table 1

Results of the chemical analysis of the samples obtained by hyperquenching at $700^{\circ} \mathrm{C}$ in the $\mathrm{Sb}_{2} \mathrm{~S}_{3}-\mathrm{AgI}$ system

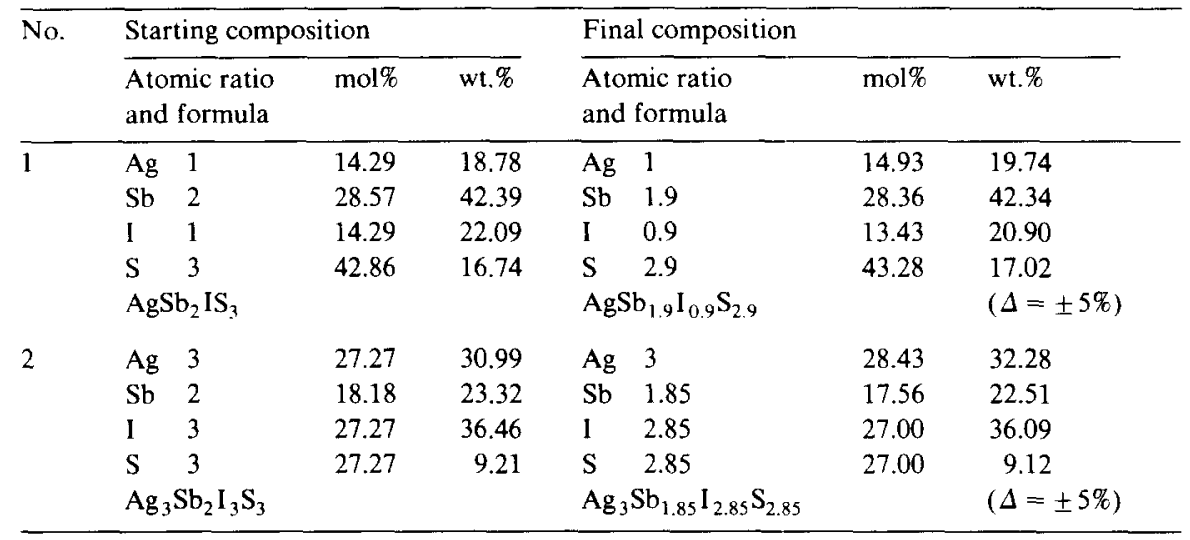

An attempt to prepare glasses by the hyperquenching method described in ref. [1] failed. Indeed, the mixtures of silver iodide and antimony sulfide give rise to volatile $\mathrm{SbSI}$ in agreement with the reaction

$$
2 \mathrm{AgI}+\mathrm{Sb}_{2} \mathrm{~S}_{3} \rightarrow \mathrm{Ag}_{2} \mathrm{~S}+2 \mathrm{SbSI} \text {. }
$$

The obtained SbSI is condensed on the cold wall of the apparatus. Hence the composition of the obtained samples is different from that of the starting mixture as shown in table 1 which summarizes the results of the chemical analysis performed by the Service Central d'Analyse du CNRS.

As a consequence, glasses described in this research have been prepared in sealed tubes with a limited free volume. The mixtures of iodide and sulfide well homogenized and pressed into pellets of about $4 \mathrm{~g}$ are put into silica containers. Those are sealed under vacuum and heated to $700^{\circ} \mathrm{C}$. After $24 \mathrm{~h}$ the container is quenched in a mixture of liquid water and ice. The glassy state of the sample is confirmed by X-ray diffraction.

The other used techniques (thermal analysis, density, chemical and electrochemical stability, electrical conductivity, transport number, infrared spectroscopy) have been previously described in ref. [1].

\section{Results}

\subsection{Glass-forming region and thermal properties}

The glass forming region is shown in the diagram of fig. 1. Only one domain is observed from $0.90 \mathrm{Sb}_{2} \mathrm{~S}_{3}-0.10 \mathrm{AgI}$ to $0.33 \mathrm{Sb}_{2} \mathrm{~S}_{3}-0.67 \mathrm{AgI}$. The color of the glasses changes from a bright black to a dark red when the silver 


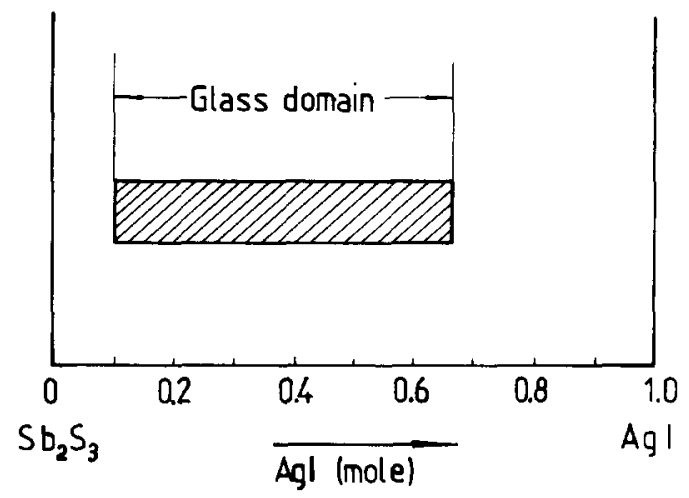

Fig. 1. Vitreous domain in the $\mathrm{Sb}_{2} \mathrm{~S}_{3}-\mathrm{AgI}$ system.

concentration increases. Figure 2 shows the variation of glass transition $\left(T_{\mathrm{g}}\right)$ and crystallisation $\left(T_{\mathrm{c}}\right)$ temperatures along the glass domain.

\subsection{Chemical stability and density}

Table 2 reports the chemical stability in water at different $\mathrm{pH}$ values. As previously observed for silver antimony sulfide glasses [1], the higher the silver content, the larger is the $\mathrm{pH}$ range where the glasses are stable.

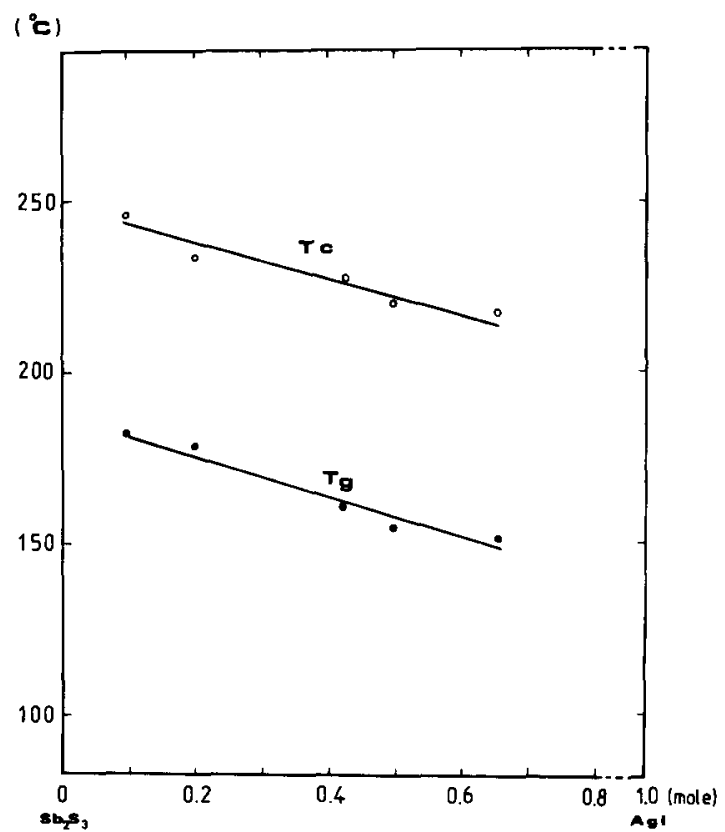

Fig. 2. Variation of $T_{\mathrm{c}}$ and $T_{\mathrm{g}}$ vs. composition in the $\mathrm{Sb}_{2} \mathrm{~S}_{3}-\mathrm{AgI}$ glass system. 
Table 2

Chemical stability of the $\mathrm{Sb}_{2} \mathrm{~S}_{3}$-AgI glasses

\begin{tabular}{llllll}
\hline $\begin{array}{l}\text { Composition } \\
(\mathrm{mol})\end{array}$ & $\begin{array}{l}\mathrm{pH} \text { value } \\
\text { of solution }\end{array}$ & $\begin{array}{l}\text { Time } \\
(\mathrm{h})\end{array}$ & $\mathrm{AgCl} \downarrow$ & $\begin{array}{l}\text { Weight loss } \\
(\%)\end{array}$ & $\begin{array}{l}\text { X-ray } \\
\text { diffr. pattern }\end{array}$ \\
\hline $0.85 \mathrm{Sb}_{2} \mathrm{~S}_{3}-0.15 \mathrm{AgI}$ & 0 & 24 & no & -8.9 & crystall. \\
& 5.5 & 24 & no & 0 & glassy \\
& 8 & 24 & no & +0.9 & glassy \\
& 11.5 & 24 & no & +3.2 & glassy \\
$0.50 \mathrm{Sb}_{2} \mathrm{~S}_{3}-0.50 \mathrm{AgI}$ & 14 & 24 & no. & +9.1 & crystall. \\
& 0 & 24 & no & -4.3 & crystall. \\
& 5.5 & 24 & no & 0 & glassy \\
& 8 & 24 & no & 0 & glassy \\
& 11.5 & 24 & no & +2.5 & glassy \\
& 14 & 24 & no & +7.2 & crystall. \\
\hline
\end{tabular}

The density of the glasses increases linearly with the silver and iodide concentration (fig. 3).

\subsection{Electrical properties}

The transport number determined for the composition $0.33 \mathrm{Sb}_{2} \mathrm{~S}_{3}-0.67 \mathrm{AgI}$ is approximately 0.995 , which shows that the electrical conductivity is mainly of ionic type due likely to silver mobility.

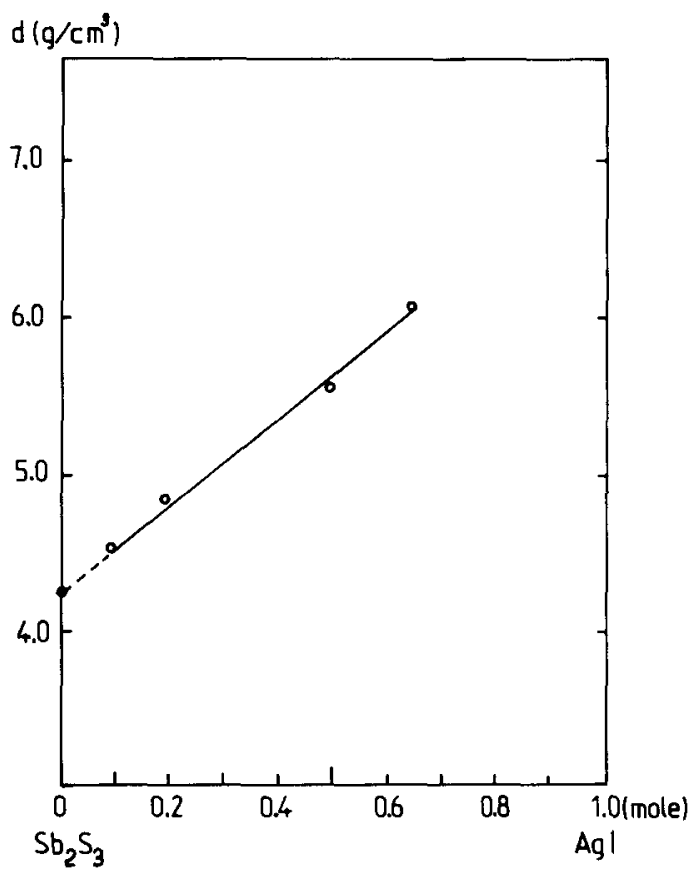

Fig. 3. Variation of the density vs. composition in the $\mathrm{Sb}_{2} \mathrm{~S}_{3}-\mathrm{Agl}$ system. 


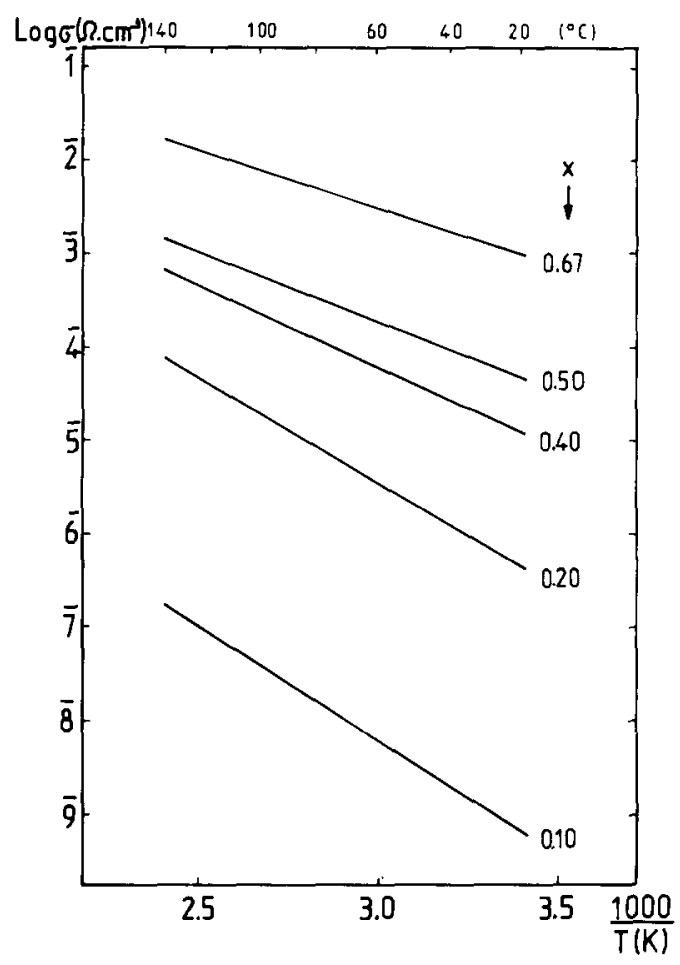

Fig. 4. Temperature dependence of the conductivity of glasses belonging to the $(1-x) \mathrm{Sb}_{2} \mathrm{~S}_{3}-x \mathrm{AgI}$ system.

Figure 4 gives the variation of the logarithm of the conductivity versus the reciprocal temperature for various compositions. An Arrhenius law is verified over the whole glass domain. Table 3 shows the values of the silver concentration, the ionic conductivity at $300 \mathrm{~K}$, the activation energy and the pre-exponential term for various glasses.

Figure 5 gives the variation of the ionic conductivity and of the activation energy vs. atomic ratio, $r=\mathrm{Ag} /(\mathrm{Ag}+\mathrm{Sb})$. The highest conductivity, i.e.,

Table 3

Values of Ag concentration, conductivity, activation energy and pre-exponential term in $\mathrm{Sb}_{2} \mathrm{~S}_{3}-\mathrm{AgI}$ glass system

\begin{tabular}{lllll}
\hline $\begin{array}{l}\text { Composition } \\
(\mathrm{mol})\end{array}$ & $\begin{array}{l}{\left[\mathrm{Ag}^{+}\right]} \\
\left(\mathrm{mol} / \mathrm{cm}^{3}\right)\end{array}$ & $\begin{array}{l}\sigma_{25^{\circ} \mathrm{C}} \\
(\Omega \cdot \mathrm{cm})^{-1}\end{array}$ & $\begin{array}{l}\Delta E_{\sigma} \\
(\mathrm{eV})\end{array}$ & $\log \sigma_{0}$ \\
\hline $0.90 \mathrm{Sb}_{2} \mathrm{~S}_{3}-0.10 \mathrm{AgI}$ & $1.37 \times 10^{-3}$ & $6.3 \times 10^{-10}$ & 0.50 & 0.7 \\
$0.80 \mathrm{Sb}_{2} \mathrm{~S}_{3}-0.20 \mathrm{AgI}$ & $3.00 \times 10^{-3}$ & $4.8 \times 10^{-7}$ & 0.44 & 1.3 \\
$0.60 \mathrm{Sb}_{2} \mathrm{~S}_{3}-0.40 \mathrm{AgI}$ & $7.31 \times 10^{-3}$ & $2.0 \times 10^{-5}$ & 0.36 & 1.2 \\
$0.50 \mathrm{Sb}_{2} \mathrm{~S}_{3}-0.50 \mathrm{AgI}$ & $9.70 \times 10^{-3}$ & $5.0 \times 10^{-5}$ & 0.30 & 0.9 \\
$0.33 \mathrm{Sb}_{2} \mathrm{~S}_{3}-0.67 \mathrm{AgI}$ & $1.49 \times 10^{-2}$ & $\underline{1.1 \times 10^{-3}}$ & $\underline{0.25}$ & 1.3 \\
\hline
\end{tabular}




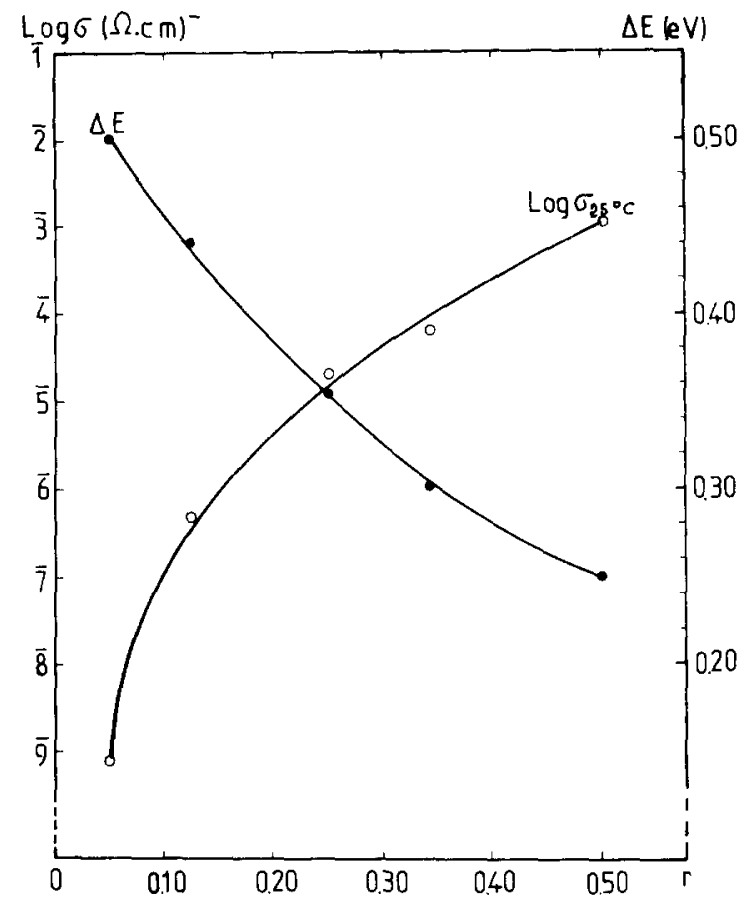

Fig. 5. Variation of the conductivity and the activation energy vs. atomic ratio $r=\mathrm{Ag} /(\mathrm{Ag}+\mathrm{Sb})$.

$\sigma_{25^{\circ} \mathrm{C}}=1.1 \times 10^{-3} \Omega^{-1} \mathrm{~cm}^{-1}$, together with the lowest activation energy $\left.\left(\Delta E_{\mathrm{o}}=0.25 \mathrm{eV}\right)\right)$ has been obtained for the composition $0.33 \mathrm{Sb}_{2} \mathrm{~S}_{3}-0.67 \mathrm{AgI}$.

\subsection{Electrochemical stability}

The voltametric curve (fig. 6) has been determined for the glass corresponding to the upper limit of the observed existence range. It corresponds to the first cycle. The curve was plotted starting with an anodic sweep at B. A slight increase in current is observed. The cathodic sweep $\mathrm{A}^{\prime}$ corresponds to silver reduction. The sharp current variation emphasizes that the silver ions are the majority carriers. During the A sweep, one observes the reoxidation of silver. The electrochemical stability is about $2 \mathrm{~V}$ with a current density of 0.1 $\mathrm{mA} / \mathrm{cm}^{2}$. This value, higher than the theoretical decomposition voltage of $\mathrm{Ag}_{2} \mathrm{~S}(0.293 \mathrm{~V})$ and that of $\mathrm{AgI}(0.689 \mathrm{~V})$, shows that the mobility of $\mathrm{S}^{2-}$ or $\mathrm{I}^{-}$ anions is quite low.

\subsection{IR spectroscopy}

Figure 7 shows the infrared absorption spectra of the vitreous $\mathrm{Sb}_{2} \mathrm{~S}_{3}$, $0.75 \mathrm{Sb}_{2} \mathrm{~S}_{3}-0.25 \mathrm{AgI}$ and $0.40 \mathrm{Sb}_{2} \mathrm{~S}_{3}-0.60 \mathrm{AgI}$ samples, together with that of crystallized AgI [5]. Pure $\mathrm{Sb}_{2} \mathrm{~S}_{3}$ is characterized by a strong band at about 275 


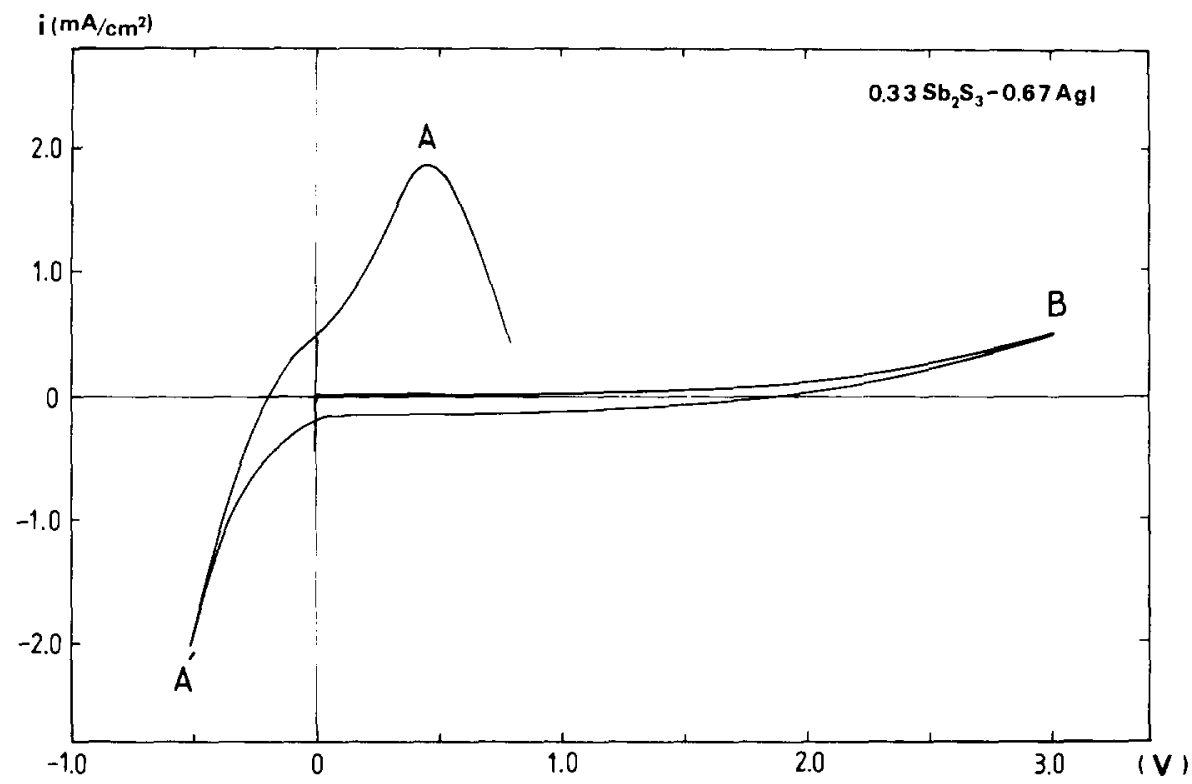

Fig. 6. Triangular voltametric curve for the glass $0.33 \mathrm{Sb}_{2} \mathrm{~S}_{3}-0.67 \mathrm{AgI}$ plotted at $35 \mathrm{mV} / \mathrm{s}$ and $25^{\circ} \mathrm{C}$.

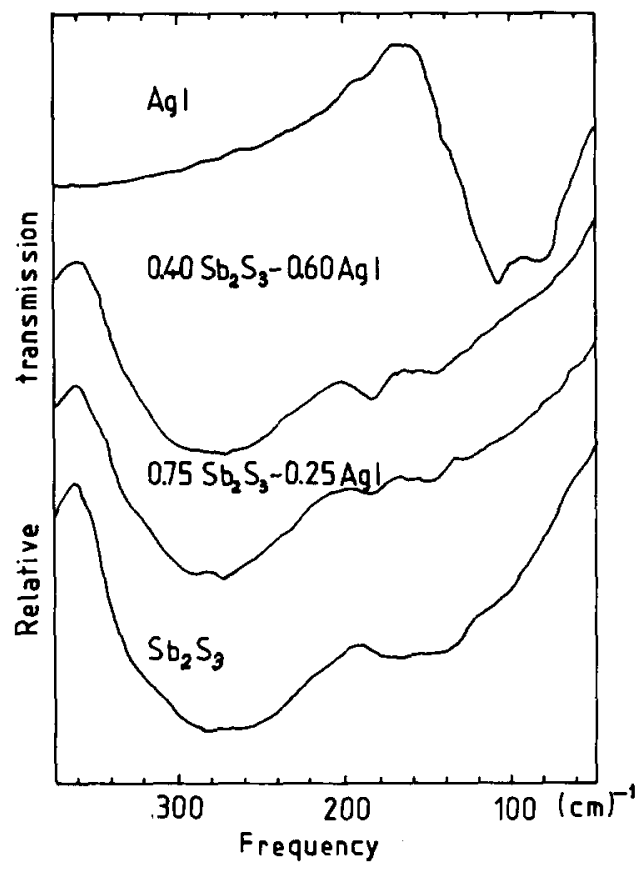

Fig. 7. Far IR absorption spectra of the glasses $\mathrm{Sb}_{2} \mathrm{~S}_{3}, 0.75 \mathrm{Sb}_{2} \mathrm{~S}_{3}-0.25 \mathrm{AgI}, 0.40 \mathrm{Sb}_{2} \mathrm{~S}_{3}-0.60 \mathrm{AgI}$ and of crystallized AgI. 


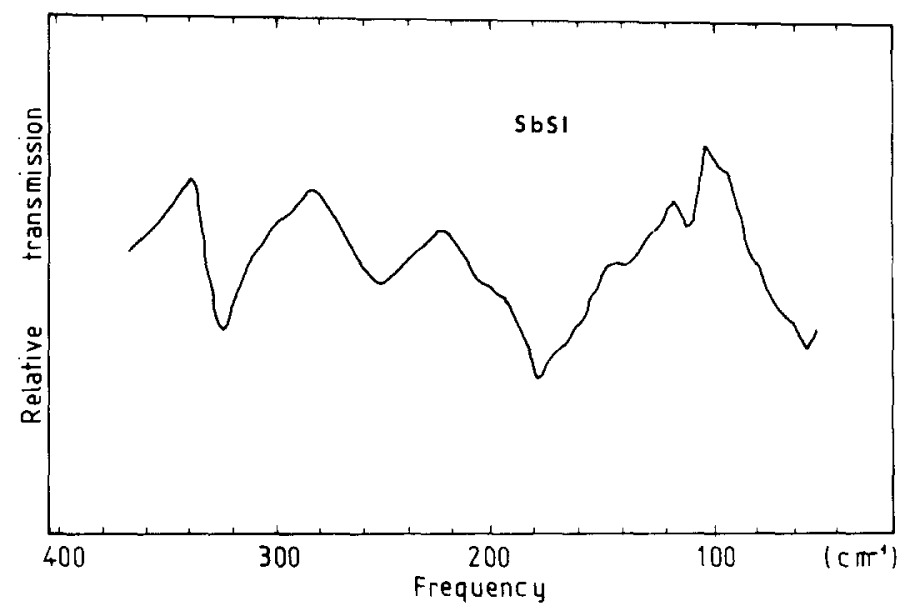

Fig. 8. IR absorption spectrum of SbSI.

$\mathrm{cm}^{-1}$ and a weaker one at about $150 \mathrm{~cm}^{-1}$ corresponding respectively to stretching and bending $\mathrm{Sb}-\mathrm{S}$ vibrations [3,4]. In the spectra of the chalcogenide glasses, those two bands are still present. In addition, one observes a weaker band at $180 \mathrm{~cm}^{-1}$. Its intensity increases with AgI content. It can be attributed by comparison with the SbSI spectrum (fig. 8) that presents a similar band. Starting from the results of the symmetry mode analysis of Petzelt [6] and Balkanski et al. [7], one may assign this band to $B_{1 u}$ and $B_{3 u}$ modes corresponding to the $\mathrm{Sb}-\mathrm{I}$ stretching vibrations in SbSI (table 4). It should be observed that the stretching vibrations in $\mathrm{SbI}_{3}$ occur at approximately the same frequency [8]. One may pay attention to the fact that the bands present in the AgI spectrum do not appear in glass spectra.

\section{Discussion}

In a previous paper, Mentus et al. found only a $0.40 \mathrm{Sb}_{2} \mathrm{~S}_{3}-0.60 \mathrm{AgI}$ glass composition in the system whereas we detected a large domain of glass [2]. The more extended domain observed by us is probably due to a higher rate of quenching. We may notice that the glass obtained by the authors corresponds to the silver-rich limit of the glass domain. The ionic conductivities measured in both investigations are of the same order of magnitude.

Taking into account the results of the IR absorption studies, it is quite likely that $\mathrm{Sb}_{2} \mathrm{~S}_{2} \mathrm{I}_{4}$ groups such as those observed in $\mathrm{SbSI}$ and $\mathrm{SbS}_{3}$ pyramids like in $\mathrm{Sb}_{2} \mathrm{~S}_{3}$ are present in our glasses (fig. 9). The substitution in the lattice of sulfur by iodine leads to partial depolymerization of the $\left(\mathrm{Sb}_{4} \mathrm{~S}_{6}\right)_{n}$ chains which characterize the $\mathrm{Sb}_{2} \mathrm{~S}_{3}$ lattice [9]. Silver ions are probably randomly located between those groups. 
Table 4

Normal modes of vibrational frequencies of SbSI with $\mathrm{D}_{2 h}$ symmetry.

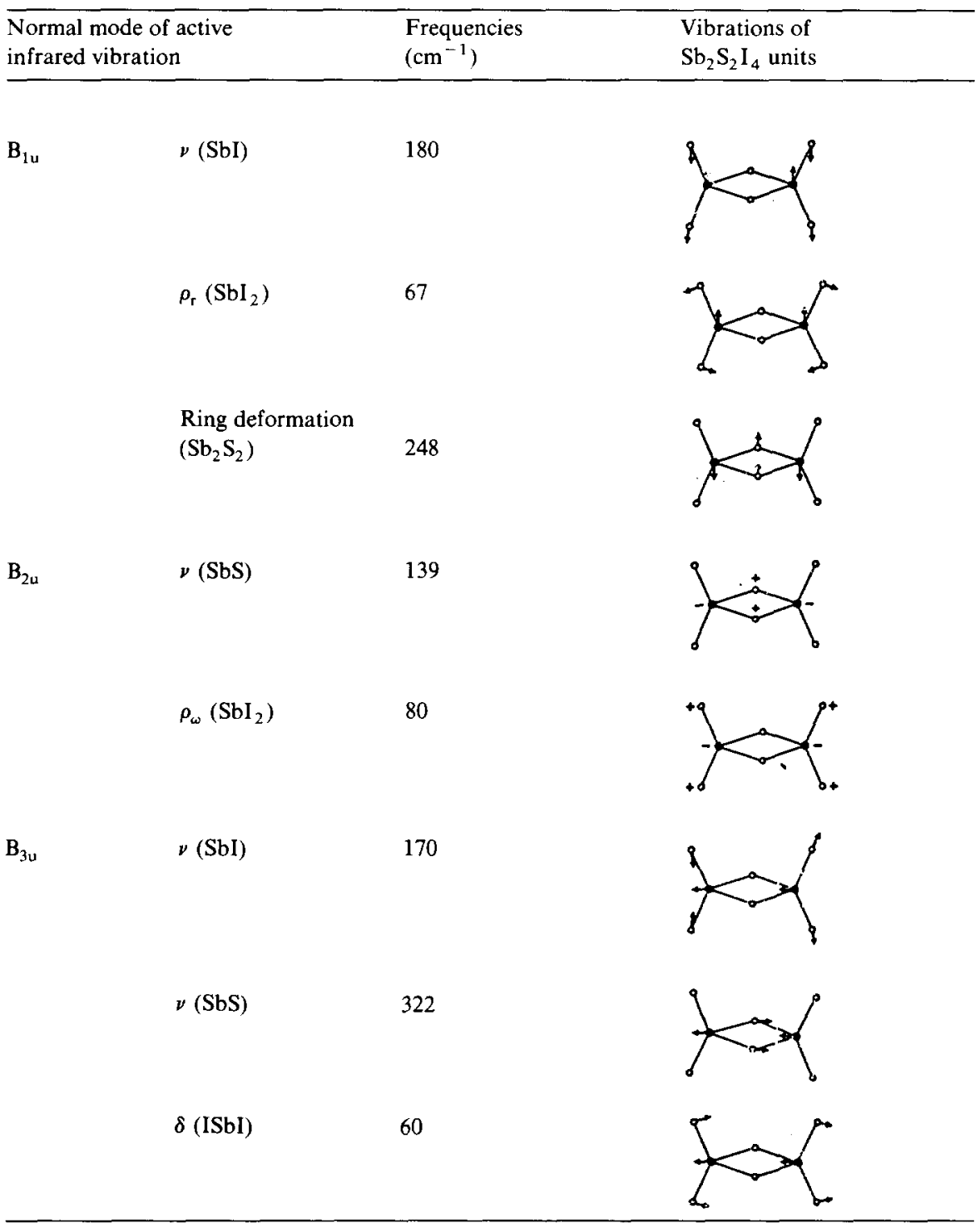

It is worthwhile to compare the ionic conductivities in the pure sulfide glasses and in thioiodide glasses in order to understand the respective influence of iodine and sulfur. We can notice that the present glasses, like those found in the first domain of the $\mathrm{Sb}_{2} \mathrm{~S}_{3}-\mathrm{Ag}_{2} \mathrm{~S}$ system, have probably a similar structure [1]. However, fig. 10 shows that at equal silver concentration the conductivity is higher and the activation energy lower in the iodide case. This 


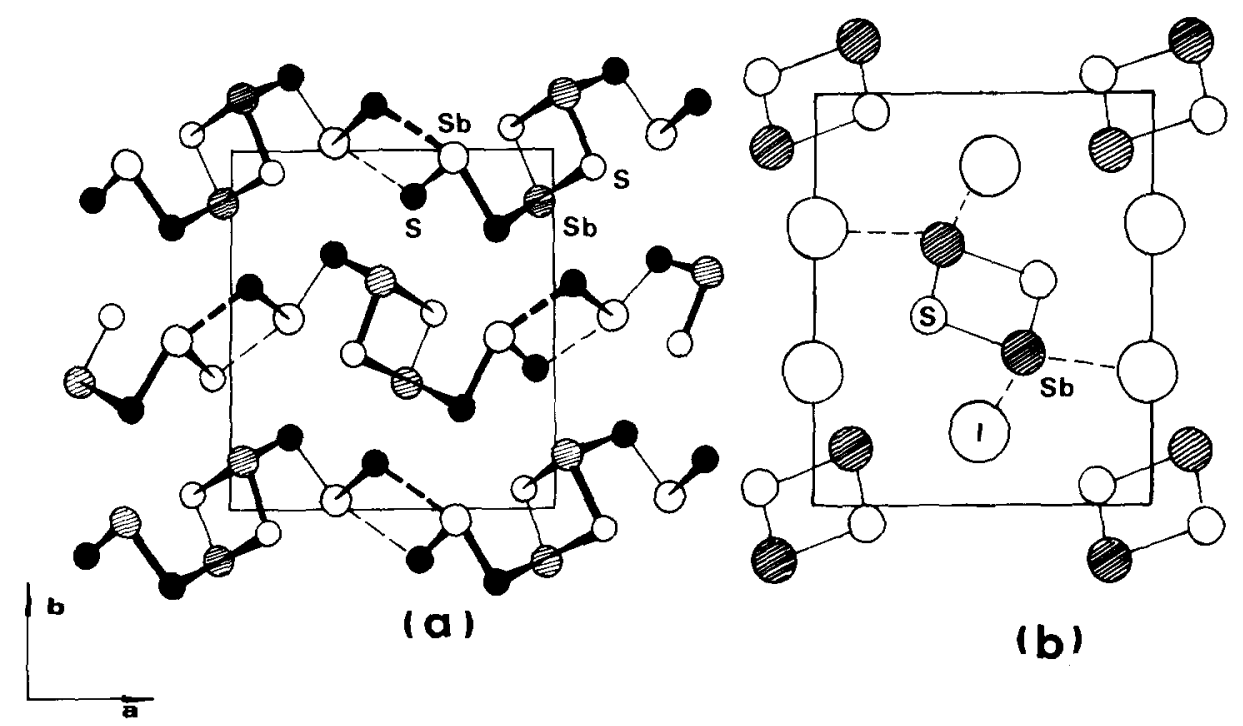

Fig. 9. Projections of the $\mathrm{Sb}_{2} \mathrm{~S}_{3}$ (a) and SbSI (b) type structures in the (001) and after [10].

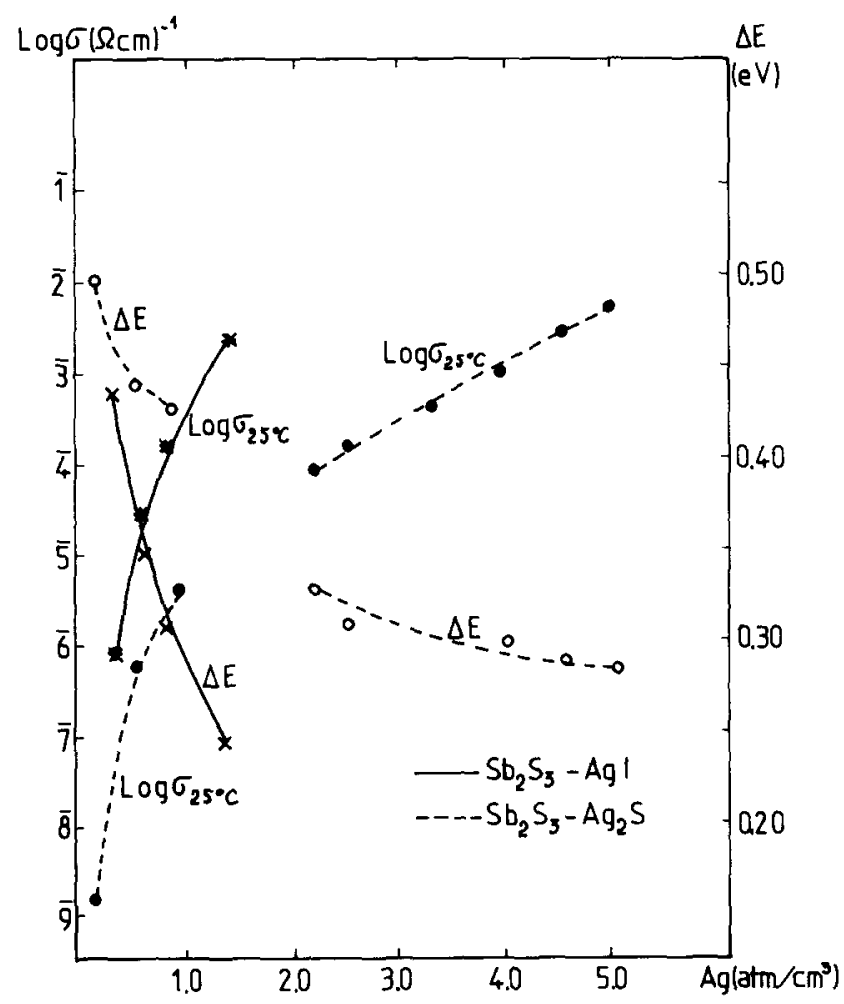

Fig. 10. Variation of $\log \sigma_{25^{\circ} \mathrm{C}}$ and $\Delta E$ as a function of the $\mathrm{Ag}$ concentration for the $\mathrm{Sb}_{2} \mathrm{~S}_{3}-\mathrm{AgI}$ and $\mathrm{Sb}_{2} \mathrm{~S}_{3}-\mathrm{Ag}_{2} \mathrm{~S}$ glass systems. 
property should be due either to weakening of the silver-lattice bond resulting from replacement of sulfur by iodine, the charge of which is lower, or to a steric effect due to large size of iodine involving an easier displacement of the $\mathrm{Ag}^{+}$ions.

We can conclude from this discussion that the best system that can be designed for a given glass former is that built up with silver sulfide which gives rise to both glass stability and high silver ion concentration and silver iodide which leads to weak silver-lattice bonding. Such superionic glasses can be expected in the $\mathrm{Ag}-\mathrm{Sb}-\mathrm{S}-\mathrm{I}$ system and will be described in a next paper [11].

\section{References}

[1] H.W. Sun, B. Tanguy, J.M. Reau, J.J. Videau and J. Portier, Mat. Res. Bull. 22 (1987) 923.

[2] S.V. Mentus, M.V. Susic and S.P. Gajinov, Sol. St. Ionics 11 (1983) 143.

[3] J.G. Poctavcev, B.P. Zacharov, V.S. Gerasinenko and L.P. Kucerenko, Izv. Akad. Nauk. SSSR, Neorg. Mat. 10 (1974) 367.

[4] J.S. Lannin, Phys. Rev. B15 (1977) 3863.

[5] G.L. Bottger and A.L. Geddes, J. Chem. Phys. 46 (1967) 3000.

[6] J. Petzelt, Ferroelectrics 5 (1973) 219.

[7] M. Balkanski, M.K. Teng, S.M. Shapiro and M.K. Ziolkiewicz, Phys. Stat. Sol. 44 (1971) 355.

[8] T.R. Manlev and D.A. Williams, Spectrochim. Acta. 21 (1965) 1773.

[9] J. Petzelt and J. Grigas, Ferroelectrics 5 (1973) 59.

[10] G.D. Christofferson and S.D. Macullorg, Acta Cryst. 12 (1954) 14.

[11] H.W. Sun, B. Tanguy, J.M. Reau, J.J. Videau, J. Portier and P. Hagenmuller J. Sol. St. Chem. 70 (1987) 141. 